\author{
Samofatova V. \\ Ph.D., Doctoral candidate \\ Department of Industrial Economics \\ Odessa National Academy of Food Technologies \\ Kanatna str., 112, Odesa, Ukraine, 65039 \\ E-mail: vica_samofatova@meta.ua
}

\title{
CLUSTER DEVELOPMENT OF THE AGRI-FOOD SPHERE OF THE SOUTHERN REGION: THE FOREIGN ECONOMIC ACTIVITY ASPECT
}

The article has analyzed the "cluster" category, the expected positive effects of the creation and development of clusters in the agri-food sphere of the Southern region have been grounded and the European clustering experience has been considered. The concept of a cluster as a unique organizational and economic formation has been investigated. The advantages of clustering in the agri-food sphere of the region for increasing its competitiveness in foreign markets have been analyzed. It has been shown, that cluster initiatives in the agri-food sphere of the regions are a popular platform for cooperation between countries. It was noted, that the regions in which the clusters function are becoming leaders in the economies of certain countries. It has been concluded, that the effectiveness of interaction in a cluster is determined by the optimality of the combination of interests of all major groups of participants. The development of clusters will be more effective if they are implemented on the basis of the principle of "reasonable specialization", that is, taking into account the unique competitive advantages of the region. In addition, success will depend on the ability to adapt to the environment.

Keywords: cluster, agri-food sphere (AFS), region, competition, cooperation, export potential.

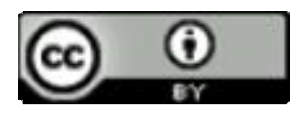

This work is licensed under a Creative Commons Attribution 4.0 International License http://creativecommons.org/licenses/by/4.0/

Statement of the problem and its connection with important scientific and practical tasks. The deepening of the processes of the international division of labor, the dynamism and the activity of the changes that are characteristic of the world trade, determine the growing role of intensification of integration processes and clusterization in the key areas of national economy at the regional level. Participation in the global processes enables regions to enter new markets for product sales and attract new technologies.

The agri-food sphere (AFS) of Ukraine is quite competitive on the world market. In the country's export potential, the share of AFS is roughly $42 \%$ by 2016 and has a steady upward trend. During the first half of 2017, the share of agricultural products in the structure of Ukrainian exports was $42.2 \%$. However, it should be noted that the basis of agrarian exports is still the export of raw materials, namely, products of plant origin wheat, corn, barley and soybeans. In January-June 2017, the total share of crop production in the structure of agrarian export of Ukraine amounted to $49.3 \%$. The main market for domestic agricultural products is the Asian market (India, Iran and Turkey), the second place is placed by the EU countries (mainly Spain, the Netherlands, Italy). The three leaders are completed with the countries of Africa (Egypt, Libya and Tunisia) [1]. At the same time, it should be emphasized that the most important part of the AFS, agriculture, belongs to the primary sectors of the economy, focused on the exploitation of national land resources and the sale of products with a low degree of processing. Preserving of the existing model of AFS development with raw orientation leads to a lack of gross value added. Therefore, the priority task is to create favorable conditions for the production of innovative products with a high level of added value.

The urgency of the problem of participation of the leading branches of the regional economy in the international division of labor is dictated by the accelerated process of integration and internationalization of the economies of different countries. Integration encompasses many forms of production (direct relationships between enterprises, deepening of specialization and cooperation processes, joint ventures, technology parks, clusters, etc.), a wide range of areas of joint research. Clustering, as a form of cooperation of enterprises in a certain area with the use of innovative technologies and combined by the process of creating a single final product, has long been practically applied in the world economy and in the regions of Ukraine. Therefore, the development of clusters in the agri-food sphere of the regions, is capable of becoming a popular platform for cooperation between countries.

The analysis of the latest publications on the problems. The study of the theoretical and practical aspects of the formation and functioning of clusters has received significant development thanks to the works of such domestic and foreign scientists: M. Voinarenko [3], 
M. Enright [12], O. Osokolsky [2], M. Porter [4], C Sokolenko, S. Figel [9] and many other researchers.

The problems of creating cluster models of development in the agri-food sphere are considered in detail by such scholars as: V. Bakum, M. Kropivko, O. Odintsov, P. Sabluk and other agrarian economists. At the same time, the theory and practice of cluster development is quite new for our country, especially in connection with the growing role of regions as independent entities of international relations.

Forming of the aims of the research. The purpose of the article is to outline the prospects for cluster development of the agri-food sphere of the Southern region in the context of foreign economic activity.

Giving an account of the main results and their substantiation. Responsibility for the sustainable development of the AFS of the region and the development of its export potential cannot be imposed only on the state and the bodies of regional management. The key role here must be played by the business, science and consumers themselves. In this sense, the most appropriate, in our opinion, is the cluster concept, in which from the scientific and practical point of view, methods of coordinated and effective interaction of business, science and the state are widely represented. A cluster is a typical example of territorial integration associations in small areas.

The phenomenon of the cluster arose with the increase of world competition at the beginning of the XXI century, which is a production and commercial structure that has the ability to concentrate, to bring together related, concomitant, and even competing manufacturers with the purpose of cooperation for the production of competitive products [2, p. 5]. A pioneer scientist in the implementation of cluster technologies in Ukraine, M. Voinarenko, formulates the notion of a cluster as a "territorially-sectoral voluntary association of enterprises that work closely with scientific institutions and local authorities in order to increase the competitiveness of their own products and economic growth of the region" [3, p. 28].

M. Porter, an acknowledged developer of cluster theory in the world, argued that "the development of well-functioning clusters is one of the most important ways on the road to a highly developed economy. To increase the level of incomes, wages and living standards, it is necessary to increase the productivity and value of products that are produced "[4, p. 299]. The concept of clusters, proposed by M. Porter, includes not only the network of enterprises, but also the presence of a strong innovation core and their relationship. Thus, the cluster is a unique economic formation, which enables its participants to be in a state of competition and, at the same time, cooperate in order to obtain additional competitive advantages. The analysis of the theories that became the basis of the use of clusters as a form of regional development revealed that they had undergone an evolution of key factors that condition the formation of a cluster of enterprises in a particular region from traditional historical ones (favorable geographical location, labor force, infrastructure, developed market of sales, to the acquired (innovative) based on [5, p. 144].
In many developed countries, clusters are actively created as a pillar of the development of regional and state economies. Great successes in the development of clusters were achieved by such countries as Germany, Belgium, Denmark, Norway, Finland and many others. In particular, as an example, we can cite the «Food Valley Cluster» in the Netherlands. In a small region of Gelderland with a radius of 30 miles around the city of Wageningen, there is a "valley" where agrobusiness, education and innovative technologies co-operate with more than 15,000 participants. The nucleus of the cluster has become the University of Wageningen, which is considered to be the best agricultural educational institution in the world. Scientific laboratories, 60 corporations, producers of technology, fertilizers, plant protection products, producers of production technologies and safety products, sewage treatment, biofuel production, energy saving, IT and nanotechnologies have united around it. In this cluster, more than $10 \%$ of the GDP of the Netherlands is created and more than 600 thousand jobs are operating, and the total population is 17 million people) $[6,7]$. At the same time, the area of the Netherlands is $41543 \mathrm{~km} 2$, the Odessa region is $33314 \mathrm{~km} 2$, and the Southern region as a whole (Odessa, Mykolaiv and Kherson regions) $86369 \mathrm{~km} 2$, that is, they are comparable in size and we, above all, need to develop clusters at the regional level. As the cluster grows, its members are developing increasingly global strategies. Understanding the competitive advantages of clusters and their active formation opens up new prospects for sustainable development and successful activity in the competitive markets in the regions.

The Organic food "Organic Valley" (OFV) Cluster, which is located in the provinces of Eastern Poland (Lublin and Podkarpackie), is an example of a cluster initiative uniting companies and organizations working in the agricultural and food sector in Poland. for cooperation and exchange of experience in the field of organic agricultural production. The profile of the cluster initiative and its location are related to the largest concentrations of organic farms in the area under study. It should be noted that in Lublin and Podkarpackie Voivodeships, almost a quarter $(23.25 \%)$ of organic producers are located in Poland. The cluster also includes the Institute of Soil Science and Plant Cultivation-National Research Institute [8].

The region's territory is a strategic network that provides certain competitive advantages that are not available for the enterprises. The region is an open stable producer community that creates a lot of space in the international division of labor, while maintaining its own way of life. Strong clusters are the driving force of the economy and are characterized by a high level of innovation and competitiveness [9, p. 18].

The share of the Southern region in the total volume of gross agricultural production in Ukraine exceeds $14.3 \%$, grain $-21.5 \%$, sunflower - $23.1 \%$, grapes $85.5 \%$, meat $-13.5 \%$, milk - $14.8 \%$, eggs $-17.3 \%$. In the structure of gross agricultural production, the share of certain types is: grain $-29.9 \%$, industrial crops $-5.9 \%$, including sunflower $-4.1 \%$, meat $-15.9 \%$, milk -13 , $3 \%$, vegetables $-10,1 \%$, fish and crustaceans $-23 \%$. The food industry is one of the leading industries in the 
region with about 2,000 enterprises. The share of agrifood products accounts for more than $46 \%$ of the total volume of export of goods from the region. In the structure of export of the region a considerable part $(41.4 \%)$ is occupied by products of plant origin [10]. In addition, the analysis of the results of foreign economic activity of the agri-food sector of the region showed that export volumes are growing in dynamics (Table 1). and there is a positive tendency to decrease the export of oilseeds, instead of the growth of oil exports.

Table 1

Commodity structure of export of certain types of products of AFS of the Southern region, ths. USA \$*

\begin{tabular}{|l|c|c|c|}
\hline \multicolumn{1}{|c|}{$\begin{array}{c}\text { Commodity structure by the areas } \\
\text { of the region }\end{array}$} & 2014 year & 2015 year & 2016 year \\
\hline Nikolaev, including & 2174097,7 & 1837492,1 & 1853063,6 \\
fish and crustaceans; & 22,8 & 47,1 & 143,4 \\
cereal crops; & 792246,7 & 761322,3 & 13098938,2 \\
oilseeds; & 1603063,6 & 161440,9 & 49858,3 \\
fats and oils & 22223,2 & 32614.8 & 1797480,4 \\
\hline Odessa, including & 1628431,2 & 1780071,2 & 107,6 \\
fish and crustaceans; & 69,2 & 66,8 & 451785,8 \\
cereal crops; & 276623,0 & 373273,6 & 127716,4 \\
oilseeds; & 1228802,2 & 202476,5 & 212290,3 \\
fats and oils & 109547,1 & 201420,2 & 438440,0 \\
\hline Kherson, including & 369051,4 & 389947,5 & 124.1 \\
fish and crustaceans; & 76,3 & 82,7 & 88322,2 \\
cereal crops; & 45917,8 & 67852,9 & 32448,7 \\
oilseeds; & 40411,9 & 51072,2 & 7525,1 \\
fats and oils & 5494,3 & 6214,6 & \\
\hline
\end{tabular}

* Formed by the author on the basis of the statistical data [10]

When formulating a strategy in the field of export activity in the region, it is necessary to take into account own opportunities and situation and trends in the world food markets. The Export potential of the region a set of natural, industrial, scientific and technical, material and technical, information and labor resources used for the development of international foreign economic relations with foreign countries. The listed resources can be effectively used only in the presence of developed forms of regional economic ties and mechanisms. The creation and effective development of clusters can be the catalyst for the foreign economic potential of the region, especially in export-oriented industries. Therefore, national competitiveness, in many respects, depends on the level of development of internal clusters and participation in international cluster projects.

Formation and development of clusters makes it possible to combine the production of certain types of agricultural products into a single technological chain from cultivation to marketing and to integrate the industrial, research and service enterprises of the AFS of the region. Creation of clusters in the agri-food sphere of the region will enable small and medium-sized producers of agri-food products to be attracted to modern international markets, as external consumers need steady batches of agri-food products and a long-term process of cooperation. Among the promising clusters in the agrifood sphere of the Southern region, first of all, it should be noted: grain, fish processing, wine-growing and and agri-tourist cluster of Odessa National Academy of Food Technologies (ONAFT)-Frumushika-Nova. The problems of their creation and development were considered in detail by the author in his works $[11,12]$. Actually, the clusters become the unique centers of innovation development, on the basis of which the structuring of the economic space is carried out and the economic and social problems of local importance are solved. Creation of clusters will contribute to the growth of productivity and innovative activity of enterprises that are part of the cluster, as well as to increase of the intensity of small and medium business development, to increase of investment attraction, which will increase the number of jobs, salaries, and revenues to budgets of all levels, increase sustainability and the competitiveness of the region's economy.

However, for the sustainable development of an integrated cluster type structure in the AFS region on an innovative basis, a cluster core is needed - a central element that is interested in the constant generation of new ideas, their implementation and diffusion. It should be noted, that in the highly developed countries, it is the research capacities of universities which act as centers of many clusters[13, p. 69]. ONAFT can become the scientific center of the Southern region, which provides comprehensive training of highly skilled specialists of various educational and qualification levels and scientific levels from the junior bachelor to the doctor of sciences and is fruitfully engaged in scientific activity. In particular, in the ONAFT the following laboratories operate: a Problem research laboratory for the integrated processing of plant raw materials in food and feed products; Laboratory for assessing the quality of grain and bakery products; Laboratory of microbiological research; the Laboratory of sensory analysis and this list can be extended considerably [14].

Conclusions and prospects of the further investigations. Global trends related to the intensification of competition have intensified the use of new regional 
development models, among which clusterization is a major factor. The results of the study have proven the advisability of introducing a clusters development model in the agri-food sphere of the South region, which operates effectively in many developed countries of the world. It is established, that the regions in which the clusters operate are becoming leaders in the economies of certain countries. It has been noted, that the formation and development of clusters makes it possible to combine the production of certain types of agricultural products into a single technological chain from cultivation to marketing, to integrate production, research and service enterprises and to ensure the growth of export potential of the region. The members of the cluster have access to technological and organizational expertise, general training opportunities and the introduction of innovative technologies. It should also be noted that the effectiveness of interaction in the cluster is determined by the optimality of the combination of interests of all major groups of participants. The cluster approach allows us to form such a mechanism of relations, which allows to obtain a profit to be equivalent to expenditure, not only by those business entities that sell ready-made food products, but also by all of the members of the association. The development of clusters will be more effective if it conforms to the principle of "smart specialization" - strengthening of the unique competitive advantages of the region. In addition, success will depend on the ability to adapt to the environment and take into account current world trends.

Prospects for further development are designed to deepen clustering efficiency research for potential cluster participants in promising AFS industries; to evaluate of the efficiency of cluster functioning and to develop programs for their further development in the context of the foreign economic activity of the region; to improve the promotion of products of participating companies on the national and international markets, and to introduce of international cooperation among similar agri-food clusters.

\title{
References
}

1. Osnovni pokaznyky zovnishnoi torhivli Ukrainy. Ofitsiinyi sait Ukrainskoho klubu ahrarnoho biznesu (UKAB). (2018). Retrieved from http://ucab.ua/ua/doing_agribusiness/zovnishni_rinki/osnovni_pokazniki_zovnishnoi_torgivli_ukraini

2. Osokolskyi, V. V. (2014). Klasteryzatsiia - vahomyi faktor pidvyshchennia konkurentospromozhnosti ekonomiky Ukrainy. Ekonomika Ukrainy, (11), 4-16.

3. Voinarenko, M. (2008). Klastery yak poliusy zrostannia konkurentospromozhnosti rehioniv. Ekonomist, (10), 27-30.

4. Porter, M. (2005). Konkurentsiya. M.: Izdatelskiy dom «Vilyams».

5. Yermakova, O. A., \& Kozak, Yu. H. (2013). Zovnishnoekonomichna diialnist rehionu. Odesa.

6. Klastery dlia Ukrainy. Koly odyn plius odyn - bilshe, nizh dva. (2016, November 22). Retrieved November 22 , 2016, from https://www.epravda.com.ua/columns/2016/11/22/611808/

7. Innovation cluster. Retrieved from https://www.foodvalley.nl/products/innovation-business-cluster/

8. List of members of the cluster. Retrieved from http://www.dolinaeko.pl/

9. Fiegel, S., Kuberska, D., \& Kufel, J. (2014, July 31). Analysis of Conditions and the State Development of Agri-Food Cluster in Poland. Retrieved July 31, 2014, from https://papers.ssrn.com/sol3/papers.cfm?abstract id=2473950

10. Samofatova, V. A. (2017). Formuvannia zernovoho klasteru yak peredumova staloho rozvytku ahroprodovolchoi sfery Pivdennoho rehionu. Rehionalna Ekonomika, (1), 30-37.

11. Samofatova, V. A. (2016). Bazovi pryntsypy stvorennia rybohospodarskoho klasteru v Pivdennomu rehioni. Ekonomichni Innovatsii, (62), 378-384.

12. Enright M. J., 1999: The Globalization of Competition and the Localization of Competitive Advantage: Policies Toward Regional Clustering, [in:] Hood N., Young S. (ed.), 1999: The Globalization of Multinational Enterprise Activity and Economic Development. Macmillan, London, after: Peters E., Hood N., 2000: Implementing the Cluster Approach. Some Lessons from the Scottish Experience. International Studies of Marketing and Organization, Vol. 30, No. 2, 68-92.

13. Naukovo-doslidnyi instytut. Ofitsiinyi sait ONAKhT. Retrieved from https://www.onaft.edu.ua/nis

Самофратова B.A.

\author{
кандидат экономических наук, докторант \\ кафедра экономики промышленности \\ Одесская национальная академия пищевых технологий \\ ул. Канатная, 112, г. Одесса, Украина, 65039 \\ E-mail: vica_samofatova@meta.ua
}

\section{КЛАСТЕРНОЕ РАЗВИТИЕ АГРОПРОДОВОЛЬСТВЕННОЙ СФЕРЫ ЮЖНОГО РЕГИОНА: ВНЕШНЕЭКОНОМИЧЕСКИЙ АСПЕКТ}

В статье отмечено, что углубление процессов международного разделения труда, динамизм и активность изменений, которые характерны для мировой торговли, определяют возрастающую роль 
интенсификации интеграционных процессов и кластеризации в ключевых сферах национальной экономики на международном уровне. Акцентировано внимание на том, что агропродовольственная сфрера Украины, является достаточно конкурентоспособной на мировом рынке, но, в основном, за счёт экспорта аграрного сырья. Показано, что кластеризация как фрорма кооперирования предприятий на определённой территории с применением инновационных технологий, уже давно получила практическое применение в мировой экономике. Приведен пример развития агропродовольственного кластера «Food Valley» в Голландии. Отмечено, что площадь Голландии сопоставима с площадью Южного региона Украины (Одесская, Николаевская и Херсонская области), поэтому нам целесообразно развивать кластеры на региональном уровне. Актуальным опытом реализации кластерных технологий также может стать кластер «Organic Food Valley» в Польше. Отмечено, что регионы, в которых функционируют кластеры становятся лидерами экономик этих стран. Показано, что для фрормирования стратегии в сфере экспортной деятельности региона, необходимо учитывать собственные возможности, а также ситуацию и тенденции на мировых рынках продовольства. Сделан вывод, что перспективными кластерами в агропродовольственной сфере Южного региона могут стать: зерновой, рыбоперерабатывающий, винодельческий и агротуристический кластер ОНАПТ-Фрумушика Нова. Формирование и развитие кластеров даёт возможность объединить производство отдельных видов агропродовольственной продукции в единую технологическую цепь от выращивания до сбыта и интегрировать производственные, научно-исследовательские и сервисные предприятия агропродовольственной сореры региона.

В статье сделан вывод, что результативность взаимодействия в кластере, определяется оптимальностью объединения интересов всех основных групп участников. Развите кластеров будет происходить эффективнее, если он будет отвечать принципу «умной специализации», то есть учитывать уникальные конкурентные преимущества региона. Кроме того, успех будет зависеть от умения адаптироваться к окружающей среде.

Ключевые слова: кластер, агропродовольственная сфера (АПС), регион, конкуренция, кооперирование, экспортный потенциал.

Самофатова B.A.

кандидат економічних наук, докторант кафедра економіки промисловості

Одеська національна академія харчових технологій

вул. Канатна, 112, м. Одеса, Україна, 65039

E-mail: vica_samofatova@meta.ua

\section{КЛАСТЕРНИЙ РОЗВИТОК АГРОПРОДОВОЛЬЧОЇ СФЕРИ ПІВДЕННОГО РЕГІОНУ: ЗОВНІШНЬОЕКОНОМІЧНИЙ АСПЕКТ}

У статті зазначено, що поглиблення процесів міжнародного поділу праці, динамізм і активність змін, які характерні для світової торгівлі, визначають зростаючу роль інтенсифікації інтеграційних процесів та кластеризації в ключових сферах національної економіки на міжнародному рівні. Акцентовано увагу на тому, що агропродовольча сфера України, є достатньо конкурентоспроможною на світовому ринку, але, в основному, за рахунок експорту аграрної сировини. Показано, що кластеризація як форма кооперування підприємств на певній території із застосуванням інноваційних технологій, вже давно отримала практичне застосування в світовій економіці. Наведено приклад розвитку агропродовольчого кластеру «Food Valley» в Голландії. Відзначено, що площа Голландії порівнянна з площею Південного регіону України (Одеська, Миколаївська та Херсонська області), тому нам доцільно розвивати кластери на регіональному рівні. Актуальним досвідом реалізації кластерних технологій також може стати кластер «Organic Food Valley» в Польщі. Відзначено, що регіони, в яких функціонують кластери стають лідерами економік цих країн. Показано, що для формування стратегії в сфрері експортної діяльності регіону, необхідно враховувати власні можливості, а також ситуацію і тенденції на світових ринках продовольства. Зроблено висновок, що перспективними кластерами в агропродовольчій сфері Південного регіону можуть стати: зерновий, рибопереробний, виноробний і агротуристичний кластер ОНАХТ-Фрумушика Нова. Формування і розвиток кластерів дає можливість об'єднати виробництво окремих видів агропродовольчої продукції в єдиний технологічний ланцюг від вирощування до збуту і інтегрувати виробничі, науково-дослідні і сервісні підприємства агропродовольчої сфери регіону.

У статті зроблено висновок, що результативність взаємодії в кластері, визначається оптимальністю поєднання інтересів усіх основних груп учасників. Розвиток кластерів буде відбуватися ефрективніше, якщо він буде здійснюватися за принципом «розумної спеціалізації», тобто враховувати 
унікальні конкурентні переваги регіону. Крім того, успіх буде залежати від уміння адаптуватися до навколишнього середовища.

Ключові слова: кластер, агропродовольча сфрера (АПС), регіон, конкуренція, кооперування, експортний потенціал.

\section{Література}

1. Основні показники зовнішньої торгівлі України. Офіційний сайт Українського клубу аграрного бізнесу (УКАБ) http://ucab.ua/ua/doing_agribusiness/zovnishni_rinki/osnovni_pokazniki_zovnishnoi_torgivli_ukraini

2. Осокольський В. В. Кластеризація - вагомий фактор підвищення конкурентоспроможності економіки України / В. В. Осокольський // Економіка України. - 2014. - № 11. - С. 4-16.

3. Войнаренко М. Кластери як полюси зростання конкурентоспроможності регіонів / М. Войнаренко // Економіст. - 2008. - №10. - С. 27-30.

4. Портер М. Конкуренция / М.Портер; пер. с англ. - М.: Издательский дом «Вильямс», 2005. - 608 с.

5. Єрмакова О. А.Зовнішньоекономічна діяльність регіону: [навч. посібник] / О.А. Єрмакова, Ю.Г. Козак - Одеса, 2013. - 332 с.

6. Кластери для України. Коли один плюс один - більше, ніж два. Українська правда. - [Електронний pecypc] - Режим доступу: https://www.epravda.com.ua/columns/2016/11/22/611808/

7. Innovation cluster. Food Valley. - [Електронний ресурс] - Режим доступу: http://www.foodvalley.nl/

8. List of members of the cluster. Organic Food Valley. - [Електронний ресурс] - Режим доступу: http://www.dolinaeko.pl/

9. Szczepan Fiegel, Dominika Kuberska and Justina Kufel (2014). An Analysis of Conditions and the State Development of Agri-Food Cluster in Poland. Multiannual Program Reports 2011-2014. 133 p. https://papers.ssrn.com/sol3/papers.cfm?abstract_id=2473950

10. Самофатова В. А. Формування зернового кластеру як передумова сталого розвитку агропродовольчої сфери Південного регіону / В. А. Самофатова // Регіональна економіка. - 2017. - № 1 - С. 30 37.

11. Самофатова В. А. Базові принципи створення рибогосподарського кластеру в Південному регіоні / В. А. Самофатова // Економічні інновації. - 2016. - Вип. 62. - С. 378-384.

12. Enright M. J., 1999: The Globalization of Competition and the Localization of Competitive Advantage: Policies Toward Regional Clustering, [in:] Hood N., Young S. (ed.), 1999: The Globalization of Multinational Enterprise Activity and Economic Development. Macmillan, London, after: Peters E., Hood N., 2000: Implementing the Cluster Approach. Some Lessons from the Scottish Experience. International Studies of Marketing and Organization, Vol. 30, No. 2, 68-92.

13. Науково-дослідний інститут. Офіційний сайт ОНАХТ. - [Електронний ресурс] - Режим доступу: https://www.onaft.edu.ua/nis 